\title{
PENGARUH DEMOGRAFIS, BRAND IMAGE DAN PERCEIVED BENEFIT TERHADAP KEPUTUSAN NASABAH MENJADI MITRA PT. BPRS LANTABUR TEBUIRENG CAB. MOJOKERTO
}

\author{
M. Musyafa' \\ Institut Agama Islam Bani Fattah Jombang, Indonesia \\ syafa.mq@gmail.com
}

\begin{abstract}
Abstrak: Perbankan merupakan suatu hal pokok dalam kehidupan masyarakat saat ini, ia mempengaruhi berbagai lini kehidupan masyarakat baik masyarakat kelas bawah menengah maupun atas. Sehingga banyak tumbuhnya Lembaga-lembaga perbankan islam swasta, yang mengakibatkan muncul persaingan dalam bisnis perbankan khususnya di Indonesia. Di tengah persaingan tersebut PT. BPRS Lantabur Tebuireng Cabang Mojokerto juga tidak luput dalam persaingan menarik orang untuk menjadi nasabah dengan berbagai langkah dan metode.
\end{abstract}

Kata kunci : Pengaruh Demografis, Nasabah, Lantabur, Tebuireng 


\section{PENDAHULUAN}

Perbankan syari'ah dalam peristilahan internasional dikenal sebagai Islamic Banking atau juga disebut dengan interest-free banking. Seperti halnya bank konvensional, bank syari'ah mempunyai fungsi utama yaitu menghimpun dana masyarakat dan menyalurkan kembali dana tersebut ke masyarakat serta memberi jasa bank lainnya. ${ }^{1}$

Pertumbuhan lembaga keuangan syari'ah di Indonesia selalu mengalami peningkatan yang signifikan setiap tahunnya. Pada outlook perbankan syari'ah 2014 tercatat sebesar 13,9\% pertumbuhan jumlah pengguna perbankan syari'ah. Adapun jumlah pekerja di perbankan syari'ah sebanyak 42.026 orang (naik 33,2\%). Dari data pekerja tersebut, tidak dipungkiri kesemuanya memiliki kemampuan sumberdaya yang mumpuni dalam hal praktek pelaksanaan sistem ekonomi Islam. ${ }^{2}$

Suatu perusahaan yang mempunyai peran penting dalam pembangunan dan pertumbuhan ekonomi nasional yaitu perusahaan di sektor keuangan. Lembaga keuangan juga sebagai aspek yang melekat dalam kehidupan masyarakat luas. Jenis dari lembaga keuangan lebih bervariasi yang meliputi perbankan, lembaga pembiayaan, usaha perasuransian, dana pensiun, pegadaian, dan pasar modal ${ }^{3}$.

Perusahaan mendapatkan laba yang sangat besar jika mereka dapat memanfaatkan fenomena yang terjadi dalam faktor demografi dengan baik. Di lain sisi, perusahaan juga harus mampu meminimalisir resiko dan ancaman yang timbul dari faktor demografi.

Segmentasi pasar secara demografi merupakan dasar yang paling populer untuk membedakan kelompok-kelompok pelanggan. Salah satu alasannya adalah keinginan, preferensi, dan tingkat pemakaian konsumen sering sangat berhubungan dengan variabel-variabel demografis. Karakteristik demografis dibutuhkan untuk mengetahui ukuran pasar sasaran dan media yang harus digunakan untuk menjangkaunya secara efisien ${ }^{4}$.

Faktor demografi merupakan salah satu faktor yang dapat dijadikan acuan dalam mengklasifikasikan suatu pasar. Kotler $^{5}$

\footnotetext{
${ }^{1}$ Muhammad, Manajemen Bank Syariah Edisi Revisi Ke-2 (Yogyakarta: UPP STIM YKPN, 2011), 15.

${ }^{2}$ Aan Zainul Anwar dan M. Yunies Edward, “Analisis Shari'ah Compliance Pembiayaan Murabahah Pada Gabungan Koperasi BMT Mitra Se-Kabupaten Jepara", The $3^{\text {rd }}$ University Research Colloquium, 2407-9189 ( Pebruari, 2016), 256.

3 Budisantoso, Totok dan Nuritom, Bank dan Lembaga Kenangan Lainnya, ( Jakarta: Salemba Empat, 2014), 6.

${ }^{4}$ Kotler, Philip dan Kevin Lane Keller, Manajemen Pemasaran, Edisi ke 12, terj., Benjamin Molan, (Jakarta: PT. Indeks, 2008), 303.

${ }^{5}$ Ibid., 304.
} 
menyatakan bahwa: In demographic segmentation, the market is divided into groups on the basis of variables such as age, family life cycle, gender, income, occupations, education, religion, race generation, nationally, social class".

Menurut Peter dan Olson ${ }^{6}$ keputusan pembelian adalah proses pengintegrasian yang mengkombinasikan pengetahuan untuk mengevaluasi dua atau lebih perilaku alternatif dan memilih salah satu diantaranya. Jika konsumen tidak memiliki pengalaman dengan suatu produk, mereka cenderung untuk mempercayai merek yang disukai atau yang terkenal ${ }^{7}$. Alasan inilah yang mendorong perusahaan untuk memperkuat posisi mereknya agar tercipta brand image yang positif dan menancap kuat di benak konsumen karena melalui brand image (citra merek), konsumen mampu mengenali sebuah produk, mengevaluasi kualitas,mengurangi resiko pembelian, dan memperoleh pengalaman dan kepuasan dari diferensiasi produk tertentu ${ }^{8}$.

Masalah yang mendasari dilakukannya penelitian ini berdasarkan kesimpulan dari beberapa hasil penelitian sebelumnya dan juga penelitian di dalam negeri yang dilakukan oleh Khoirunissa, ${ }^{9}$ yang menganalisa faktor-faktor motivasi nasabah dalam menabung pada bank Islam dengan tiga variabel penelitian yakni, faktor ekonomi, faktor religius, faktor eksternal. Penelitian Ratnawati, $\mathrm{dkk},{ }^{10}$ dengan variabel yang diteliti adalah motivasi nasabah dipengaruhi oleh banyak faktor: (1) varabel demografi, (2) variabel ekonomi, dan (3) variabel sosial. Penelitian Fatmah, ${ }^{11}$ variabel yang diteliti adalah ketaatan mereka terhadap syari'ah (religious motive), economic motive, variabel kepercayaan dan loyalitas.

PT. BPR Syari'ah Lantabur adalah sebuah lembaga keuangan/ perbankan pertama di wilayah Jombang yang beroperasi berdasarkan

\footnotetext{
${ }^{6}$ Peter, J. Paul dan Jerry C. Olson, Consumer Behavior. Perilaku konsumen dan Strategi Pemasaran. Jilid 2. Edisi 4. terj., Damos Sihombing, (Jakarta: Erlangga, 2000), 162.

${ }^{7}$ Schiffman, Leon dan Leslie L. Kanuk, Perilaku Konsumen. Edisi Ketujuh, terj., Zoelkifli Kasip (Jakarta: Indeks, 2008), 173.

8 Lin, Nan-Hong dan Bih-Syah Lin, "The Effect of Brand Image and Product Knowledge on Purchase Intention Moderated by Price Discount", Journal of International Managements Studies, No. 3 (Agustus, 2007), 121-132.

${ }_{9}$ Khoirunnisa, Delta, "Consumers Preference Toward Islamic Banking Case Study in Bank Muamalat Indonesia and Bank BNI syari'ah”, IQTIS AD Journal of Islamic Economic. Vol. 4 , No.2 ( September, 2003), 145-168.

10 Ratnawati, Nirdukita, "Analisis Pengaruh Variabel Indikator Makro Ekonomi Terhadap Ekonomi Makro Indonesia Periode 1990-2003”, Media Ekonomi Vol. 10 No. 3 (2004), 291-308.

${ }^{11}$ Fatmah, 'Pengaruh Persepsi Religiusitas, Kualitas Layanan, dan Inovasi Produk terhadap Kepercayaan dan Komitmen sertaLoyalitas Nasabah Bank Umum Syari'ah di Jawa Timur", (Disertasi-- UNAIR, Surabaya, 2004), 67.
} 
prinsip Syari'ah, diawali dengan keinginan untuk dapat menjalankan perekonomian secara islami dan usaha untuk meningkatkan perekonomian ummat di wilayah Jombang dan sekitarnya, maka dengan diprakarsai oleh para pimpinan PP. Madrasatul Qur'an Tebuireng dan masyarakat yang peduli terhadap perekonomian ummat maka dibentuklah Lembaga Keuangan yang bernama PT. BPR Syari'ah Lantabur. ${ }^{12}$ Demi meningkatkan kualitas pelayanan dan mejaga kepercayaan dari masyarakat, BPRS Lantabur juga menjadi anggota Lembaga Penjamin Simpanan (LPS). Untuk lebih menguatkan nilai jual di masyarakat, pada tahun 2014 PT BPRS Lantabur berganti nama menjadi PT BPRS Lantabur Tebuireng ${ }^{13}$. Setelah 4 tahun melakukan kegiatan operasinal PT. BPRS Lantabur membuka 2 kantor pelayanan kas yang berlokasi di Jl. Irian Jaya 47-A Cukir Diwek Jombang dan di Jl. Sumobito Gambiran Utara Mojoagung Jombang. Pada November tahun 2010 telah dibuka Kantor Cab. di Kab. Mojokerto ${ }^{14}$

Berdasarkan latar belakang yang telah disampaikan, penulis merasa tertarik untuk mengadakan penelitian Analisis Pengaruh Demografis, Brand Image dan Perceived Benefit Terhadap Keputusan Nasabah Dalam Memilih Menjadi Mitra PT. BPRS Lantabur Tebuireng Cab. Mojokerto. Dengan fokus penelitian pengaruh signifikan dari masingmasing variabel serta variabel mana yang paling signifikan terhadap keputusan nasabah dalam memilih menjadi mitra PT. BPRS Lantabur Tebuireng Cab. Mojokerto.

\section{PEMBAHASAN}

\section{Analisis Variabel Demografi Terhadap Keputusan Nasabah Dalam Memilih Menjadi Mitra PT. BPRS Lantabur Tebuireng Cab. Mojokerto.}

Demografi dalam perbankan sangat penting untuk mengetahui sasaran dalam segmentasi pasar sehingga perusahaan atau bank dapat membuat produk yang sesuai untuk target konsumen.

Hasil tanggapan responden yang berjumlah sebanyak 80 nasabah atas kuesioner penelitian akan diuraikan dalam bentuk tabel tabulasi frekuensi dengan skor untuk setiap dimensi. Berdasarkan skor serta persentase yang dicapai untuk setiap dimensi variabel selanjutnya ditentukan pengkategorian berdasarkan penentuan kriteria berikut:

12 Izin Pendirian berdasarkan keputusan MENKUMHAM No.C 7026. HT.01.01.TH.2005 dan Ijin Usaha dari Bank Indonesia No.8/4/KEP.GBI/2006 tertanggal 01 Maret 2006 (dokumentasi perusahaan)

${ }^{13}$ Sesuai dengan keputusan MENKUMHAM No AHV-16377.AH.01.02 Tahun 2014 (dokumentasi perusahaan)

${ }^{14}$ Foto prasasti pembukaan terlampir 
perolehan skor maksimum setiap kuesioner adalah 5 atau 100\% dan skor minimum adalah 1 atau 20\% dari skor maksimum. Jarak amtara skor yang berdekatan adalah satu per lima dari selisih nilai maksimum dengan nilai minimum atau sama dengan 16\% dari nilai maksimum 100\%. Selanjutnya diperoleh interval persentase skor untuk setiap kategori adalah sebagai berikut:

a. $84 \%$ sampai dengan $100 \%$ dikategorikan sangat baik

b. $68 \%$ sampai dengan 83,99 dikategorikan baik

c. $52 \%$ sampai dengan $67,99 \%$ dikategorikan cukup baik

d. 36\% sampai dengan $51,99 \%$ dikategorikan tidak baik

e. $20 \%$ sampai dengan 35,99\% dikategorikan sangat tidak baik.

Variabel demografi yang dilihat dalam penelitian ini merupakan unsurunsur yang membangun demografi dalam penentuan segmentasi pasar dalam perbankan. Variabel ini tercermin dari beberapa indikator yaitu Jenis Kelamin, Usia, Pekerjaan, Pendidikan terakhir, dan Pendapatan rutin yang diterima.

\section{a. Jenis kelamin.}

Dari pertanyaan yang diajukan persentase skor yang diperoleh dari tanggapan 80 responden (43 orang atau 53,7\% menjawab berjenis kelamin perempuan, 37 orang atau 46,3\% menjawab bergender laki-laki) menghasilkan jawaban berada pada criteria sangat baik. Hasil ini menunjukkan bahwa tidak ada transaksi yang mengindikasikan adanya riba, gharar, atau meisir pada PT. BPRS Lantabur Tebuireng Mojokerto.

\section{b. Usia}

Hasil tanggapan responden (40 orang atau 50\% menjawab berusia kisaran 30,39 tahun.. Kemudian 20 orang atau 25\% berusia 40-49 tahun, sedangkan 15 atau $18,75 \%$ berusia 20-29 tahun. Sisanya 5 orang atau 6,25\% berusia diatas 50 tahun. Sedangkan yang berusia 10-20 tahun tidak ada sampel dikarenakan produk tabumgan yang dikeluarkan tidak untuk segmentasi anak atau remaja )terhadap item pernyataan yang digunakan menunjukkan persentase skor yang diperoleh dari tanggapan 80 responden berada pada criteria cukup baik. Hasil ini menunjukkan bahwa karakteristik dapat mempengaruhi perilaku konsumen termasuk dalam mengelola keuangan personal pada nasabah yang ada pada PT. BPRS Lantabur Tebuireng Mojokerto.

\section{c. Pekerjaan}

Hasil tanggapan responden(jawaban responden terdeteksi yaitu 13 orang atau 16,5\% nasabah bekerja dengan jenis pekerjaan lain-lain yang disini sesuai dengan hasil wawancara dan observasi adalah kuli, penjaga toko, ibu rumah tangga. Kemudian 17 orang atau 21,25\% bekerja sebagai PNS dan 22 atau 27,5\% Pegawai Swasta. Sedangkan sisanya 28 orang atau 35\% sebagai pedagang atau berwiraswasta. Dan yang bekerja sebagai 
TNI atau Polri sebanyak 0 orang atau $0 \%$ ) terhadap item pernyataan yang digunakan Terlihat persentase skor yang diperoleh dari tanggapan 80 responden berada pada criteria baik. Hasil ini menunjukkan bahwa jenis pekerjaan berpengaruh terhadap perilaku nasabah.

\section{d. Pendidikan}

Dimensi pendidikan terakhir yang ditempuh oleh responden (5 orang atau $6 \%$ nasabah lulusan SD. Kemudian 8 orang atau $10 \%$ lulusan SMP dan 20 orang atau 25\% lulusan SMA. Sedangkan 40 orang atau $50 \%$ setara diploma dan sarjana. Dan sisanya 7 orang atau 9\% setara S2.) Hasil tanggapan responden berada pada criteria baik.

\section{e. Pendapatan}

Hasil tanggapan responden terhadap item pernyataan yang digunakan yaitu 0 orang atau $0 \%$ menjawab berpendapatan kurang dari Rp.500.000. Dan 11 orang atau 13,75\% menjawab berpendapatan antara Rp.500.000-Rp. 1.000.000. Sedangkan yang menjawab berpendapatan lebih dari Rp.1.000.000 adalah 34 orang atau 42,5\% begitu juga yang menjawab berpendapatan lebih dari Rp. 2.000 .000 adalah 34 orang atau 42,5\%. Sisanya yang menjawab lebih dari Rp. 5.000.000 hanya 1 orang saja.

\section{Analisis Variabel Brand Image Terhadap Keputusan Nasabah Dalam Memilih Menjadi Mitra PT. BPRS Lantabur Tebuireng Cab. Mojokerto.}

Brand image (citra merek) merupakan gambaran atau kesan yang ditimbulkan oleh suatu merek dalam benak pelanggan. Penempatan citra merek dibenak konsumen harus dilakukan secara terus-menerus agar citra merek yang tercipta tetap kuat dan dapat diterima secara positif.

Menurut Biel (1992) dalam jurnal Xian, $\mathrm{dkk}^{15}$ brand image memiliki tiga komponen yaitu corporate image (citra perusahaan), user image (citra pemakai), dan product image (citra produk). Citra dari sebuah perusahaan berawal dari perasaan pelanggan dan para pelaku bisnis tentang organisasi yang bersangkutan sebagai produsen produk tersebut sekaligus sebagai hasil evaluasi individual tentang hal tersebut. Xian, $\mathrm{dkk}^{16}$ menyatakan bahwa "The user image refers to whether the brand personality is congruent with the consumers." Citra pemakai mengacu pada apakah kepribadian merek sesuai dengan konsumen. Sedangkan citra produk adalah suatu pandangan masyarakat terhadap suatu produk atau

\footnotetext{
15 Xian, Gou Li, dkk. 2011. "Corporate-, Product-, and User-Image Dimensions and Purchase Intentions” Journal of Computers Vol.6 No. 9 (2011), 1876.

${ }^{16}$ Ibid., 1879.
} 
kategori suatu produk. Untuk mengukur dimensi tersebut dalam penelitian ini digunakan kuesioner dengan jumlah 9 item pernyataan dengan tiga indicator, yaitu citra perusahaan, citra pemakai itu sendiri/konsumen, dan citra produk yang masing-masing terbagi dalam 3 pernyataan.,

\section{a. Dimensi Citra Perusahaan}

Dimensi citra perusahaan Terlihat persentase skor yang diperoleh dari tanggapan 80 responden berada pada criteria sangat baik.

Distribusi jawaban responden yaitu popularitas, mayoritas responden menjawab sangat popular yaitu 15 orang atau $18,75 \%$. Sedangkan 37 orang atau 46,25\% menjawab popular, kemudian 24 orang atau $30 \%$ menjawab cukup popular sisanya 4 orang atau $5 \%$ menjawab tidak popular.

Sedangkan kredibilitas responden menjawab sangat kredibel sebanyak 12 orang atau 15\%, Kemudian 29 orang atau 36,8\% menjawab punya kredibilitas. Sedangkan 28 orang atau 35\% menjawab cukup kredibvel. Sisanya 11 orang atau 13,75\% menjawab tidak kredibel.

Berikutnya adalah jaringan perusahaan, jawaban responden yaitu 13 orang atau 16,25\% menjawab sangat banyak, Kemudian 32 orang atau $40 \%$ menjawab banyak, sedangkan 20 orang atau 25\% menjawab cukup dan sisanya 15 orang atau $18,75 \%$ menjawab tidak banyak.

\section{b. Dimensi Citra Produk}

Terlihat persentase skor yang diperoleh dari tanggapan 74 responden berada pada criteria cukup baik.

Distribusi jawaban responden sebagai pemakai produk itu sendiri yang merasa nyaman bertransaksi di PT. BPRS Lantabur Tebuireng karena dijamin kehalalannya dan memiliki produk-produk yang menurut mereka sesuai syari'ah. Responden menjawab tidak sesuai dengan diri sendiri yaitu 2 orang atau 2,5\%. Berikutnya 29 orang atau 36,25\% menjawab biasa saja . Dan 36 orang atau $45 \%$ menjawab baik dan sisanya 13 orang atau 16,25\% menjawab sangat baik. Pernyataan berikutnya yaitu gaya hidup/kepribadian. Responden menjawab tidak sesuai gaya hidup sebanyak 2 orang atau 2,5\%, Berikutnya 23 orang atau 28,75\% menjawab biasa saja, sedangkan 42 orang atau 52,5\% menjawaab sesuai dengan gaya hidup yang islami. Sisanya 13 orang atau 16,25\% menjawab sangat setuju. Berikutnya adalah pernyataan tentang status sosial. Responden menjawab yaitu 14 orang atau $17,5 \%$ menjawab tidak meningkatkan status sosial. Kemudian 28 orang atau 35\% menjawab menjawab biasa saja tidak ada efek. Sedangkan 24 orang atau 30\% menjawab setuju dan sisanya 14 orang atau $17,5 \%$ menjawab sangat setuju.

\section{c. Dimensi Citra Konsumen}


Dimensi citra knsumen tanggapan responden terlihat persentase skor yang diperoleh dari tanggapan 80 responden berada pada criteria baik.

Distribusi jawaban responden untuk pernyataan atribut produk, Responden menjawab tidak setuju yaitu 12 orang atau15\%. Kemudian 37 orang atau 46,25\% menjawab biasa saja. Sedangkan 27 orang atau $33,75 \%$ menjawab setuju, sisanya 4 orang atau 5\% menjawab sangat setuju. Sedangkan pernyataan berikutnya yaitu manfaat bagi konsumen. Responden menjawab tidak bermanfaat sebanyak 13 orang atau $16,25 \%$, Sedangkan 36 orang atau $45 \%$ menjawab biasa saja, diikuti 27 orang atau $33,75 \%$ menjawab bermanfaat. Sedangkan sisanya 4 orang atau 5\% menjawab sangat bermanfaat. Pernyataan berikutnya adalah jaminan. Responden menjawab tidak ada jaminan yaitu 15 orang atau $18,75 \%$. Kemudian 38 orang atau 47,5\% menjawab biasa saja. Sedangkan 23 orang atau $28,75 \%$ menjawab terjamin, sisanya 4 orang atau $5 \%$ yang menjawab sangat terjamin.

\section{Analisis Variabel Perceived Benefit Terhadap Keputusan Nasabah Dalam Memilih Menjadi Mitra PT. BPRS Lantabur Tebuireng Cab. Mojokerto.}

Persepsi Manfaat merupakan keyakinan konsumen tentang sejauh mana ia akan menjadi lebih baik dari. Persepsi Manfaat juga bisa diasumsikan adalah sejauh mana seseorang percaya bahwa penggunaan suatu produk akan meningkatkan kualitas hidupnya. Variabel ini tercermin dari beberapa indikator yaitu meningkatkan fleksibilitas, meningkatkanefisiensi, meningkatkan efektifitas, dan berguna untuk banyak transaksi. Untuk mengukur dimensi tersebut dalam penelitian ini digunakan kuesioner dengan jumlah 3 item yaitu:

\section{a. Dimensi Meningkatkan Fleksibilitas}

Dimensi meningkatkan meningkatkan fleksibilitas, mayoritas responden menjawab tidak fleksibel sebanyak 16 orang atau $20 \%$. Berikutnya sebanyak 36 orang atau $45 \%$ menjawab biasa saja, sedangkan 24 orang atau $30 \%$ menjawab setuju ada fleksibilitas. Sisanya 4 orang atau $5 \%$ menjawab sangat setuju.

\section{b. Dimensi Meningkatkan Efisiensi}

Dimensi meningkatkan efisiensi terlihat persentase skor yang diperoleh dari tanggapan 80. responden berada pada kriteria baik. PT. BPRS Lantabur Tebuireng Cab. Mojokerto dengan program dan produknya telah memberikan efisiensi untuk kegiatan saya sehari-hari. Responden menjawab tidak setuju sebanyak 14 orang atau 17,5\%. Berikutnya 36 orang atau 45\% menjawab biasa saja. Sedangkan 24 orang 
atau 30\% menjawab setuju. Sisanya 6 otang atau 7,5\% menjawab sangat setuju.

\section{c. Dimensi Meningkatkan Efektifitas}

Dimensi meningkatkan efektifitas Terlihat persentase skor yang diperoleh dari tanggapan 80 responden berada pada kriteria cukup baik. Distribusi jawaban responden untuk pernyataan meningkatkan efektifitas, responden menjawab tidak setuju yaitu 13 orang atau 16,25\%. Kemudian 38 orang atau 47,5\% menjawab biasa saja. Sedangkan 27 orang atau 33,75\% menjawab setuju, sisanya 2 orang atau 2,5\% menjawab sangat setuju.

\section{d. Dimensi Berguna Untuk Banyak Transaksi}

Dimensi berguna untuk banyak transaksi Terlihat persentase skor yang diperoleh dari tanggapan 80 responden berada pada kriteria cukup baik. Responden menjawab tidak setuju sebanyak 12 orang atau 15\%. Berikutnya 39 orang atau 48,75\% menjawab biasa saja. Sedangkan 22 orang atau $27,5 \%$ menjawab setuju. Sisanya 7 otang atau $8,75 \%$ menjawab sangat setuju.

\section{Analisis Variabel Keputusan Memilih}

Keputusan memilih merupakan suatu keputusan yang diambil oleh pihak nasabah dalam melakukan pemilihan pada PT. BPRS Lantabur Tebuireng Cab. Mojokerto. Keputusan Memilih yang dilihat dalam penelitian ini merupakan unsur-unsur dimana nasabah mampu menilai dan memilih produk atau jasa terhadap apa yang telah diterimanya/digunakannya dari PT. BPRS Lantabur Tebuireng Mojokerto. Variabel ini diukur dalam 4 (empat) imdikator yaitu fasilitas memadai, pengaruh, manfaat serta hadiah-hadiah menarik. Untuk mengukur indikator tersebut dalam penelitian ini digunakan kuesioner dengan jumlah item pernyataan untuk mengukur ketiganya adalah 4 item.

\section{a. Dimensi Fasilitas Yang Memadai}

Dimensi fasilitas yang memadai dilihat beerdasarkan 1 item pernyataaan yaitu PT. BPRS Lantabur Tebuireng Cab. Mojokerto telah memiliki fasilitas yang memadai untuk saya gunakan sehari-hari. Hasil tanggapan responden dari tanggapan 74 responden berada pada criteria cukup baik. Distribusi jawaban responden untuk pernyataan ini yaitu 12 orang atau 15\% menjawab tidak setuju. Kemudian 36 orang atau 45\% menjawab biasa saja. Sedangkan 28 orang atau 35\% menjawab setuju dan sisanya 4 orang atau $5 \%$ menjawab sangat setuju.

\section{b. Dimensi Pengaruh}

Dimensi pengaruh dilihat berdasarkan pernyataaan yaitu saya merasa terpengaruh dengan rekan atau saudara yang menggunakan produk PT. BPRS Lantabur Tebuireng Cab. Mojokerto. Hasil tanggapan menunjukkan bahwa responden sebanyak 10 orang atau $12,5 \%$ 
menjawab tidak terpengaruh. Kemudian 39 orang atau 48,75\% biasa saja. Sedangkan 26 orang atau 32,5\% terpengaruh dan sisanya 5 atau 6,25\% sangat terpengaruh. Terlihat persentase skor yang diperoleh dari tanggapan 80 responden berada pada criteria cukup baik.

\section{c. Dimensi Manfaat}

Dimensi manfaat dilihat responden menjawab tidak bermanfaat 13 orang atau $16,25 \%$ Berikutnya sebanyak 35 orang atau 43,75\% menjawab biasa saja, sedangkan 27 orang atau 33,75\% menjawab bermanfaat dan sisanya 5 atau $6,25 \%$ akan sangat bermanfaat. Persentase skor yang diperoleh dari tanggapan 80 responden berada pada criteria cukup baik.

\section{d. Dimensi Hadiah yang Menarik}

Dimensi memberikan hadiah yang menarik dilihat berdasarkan pernyataaan yaitu nasabah memutuskan untuk menggunakan produk PT. BPRS Lantabur Tebuireng Cab. Mojokerto dikarenakan ada hadiah atau souvenir yang menarik diberikan pada nasabah. Hasil tanggapan responden terhadap item pernyataan yang digunakan yaitu 14 orang atau $17,5 \%$ menjawab tidak ada hadiah. Berikutnya sebanyak 33 orang atau $41,25 \%$ menjawab biasa saja, sedangkan 28 orang atau 35\% menjawab ada dan sisanya 5 orang atau $6,25 \%$ menjawab selalu ada hadiah atau souvenir. Terlihat persentase skor yang diperoleh dari tanggapan 80 responden berada pada criteria cukup baik.

\section{Hasil Penelitian Olah Data PLS (Partial Least Square)}

Penjabaran model persamaan dasar dari Inner Model PLS (Partial Least Sturctural) pada penelitian dapat diterjemahkan dan ditulis sebagai berikut

$\eta=\eta \beta+\xi \Gamma+\zeta$

Keputusan Memilih $=\xi_{1}$ Demografi $+\xi_{2}$ Brand Image $+\xi_{3}$ Perceived Benefit + Error

1. Evaluasi Measurement (Outer) Model

\section{a. Uji Validitas}

Menurut Ghozali ${ }^{17}$ suatu indikator dianggap valid jika memiliki nilai korelasi di atas 0,70. Namun untuk loading factor 0,50 sampai 0,60 masih dapat diterima dengan melihat output korelasi antara indikator dengan konstruknya yang dituju. Hasil Outer loadings (measurement model) atau validitas konvergen digunakan untuk menguji unidimensionalitas dari masing-masing konstruk. Nilai indikator loading factor yang lebih besar atau sama dengan 0,5 dapat dikatakan valid. ${ }^{18}$ Output SmartPLS loading factor memberikan hasil sebagai berikut:

\footnotetext{
${ }^{17}$ Hengky Latan dan Imam Ghozali, Partial Least Squares: Konsep, Teknik dan Aplikasi dengan program SmartPLS 2.0 M3 (Semarang: BP UNDIP, 2012), 96.

${ }^{18}$ Ibid., 96.
} 


\section{RESULT FOR OUTER LOADING}

\begin{tabular}{|c|c|c|c|c|}
\hline & Brand Image & Demografi & Keputusan & Perceived Benefit \\
\hline Ben1 & & & & 0,919 \\
\hline Ben2 & & & & 0,961 \\
\hline Ben3 & & & & 0,911 \\
\hline Ben4 & & & & 0,833 \\
\hline Brim1 & 0,660 & & & \\
\hline Brim2 & 0,791 & & & \\
\hline Brim3 & 0,728 & & & \\
\hline Brim4 & 0,810 & & & \\
\hline Brim5 & 0,831 & & & \\
\hline Brim6 & 0,904 & & & \\
\hline Brim7 & 0,870 & & & \\
\hline Brim8 & 0,912 & & & \\
\hline Brim9 & 0,904 & & & \\
\hline Dem1 & & 0,815 & & \\
\hline Dem2 & & 0,760 & & \\
\hline Dem3 & & 0,602 & & \\
\hline Dem4 & & 0,827 & & \\
\hline Dem5 & & 0,868 & & \\
\hline Kep1 & & & 0,949 & \\
\hline Kep2 & & & 0,974 & \\
\hline Kep3 & & & 0,985 & \\
\hline Kep4 & & & 0,960 & \\
\hline
\end{tabular}

Pengujian validitas untuk indikator reflektif menggunakan korelasi antara skor item dengan skor konstruknya. Pengukuran dengan indikator reflektif menunjukkan adanya perubahan pada suatu indikator dalam suatu konstruk jika indikator lain pada konstruk yang sama berubah (atau dikeluarkan dari model). Indikator reflektif cocok digunakan untuk mengukur persepsi sehingga penelitian ini menggunakan indikator reflektif. Pada table diatas menunjukkan bahwa loading factor memberikan nilai di atas nilai yang disarankan yaitu sebesar 0,5. Nilai paling kecil untuk variable Demografi adalah 0,602 yaitu indicator Dem3 sedangkan 
paling besar adalah indicator Dem5 yaitu 0,868. Untuk variable Brand Image nilai loading factor paling kecil adalah 0,660 pada indicator Brim1 sedangkan paling besar adalah 0,912 pada indicator Brim8. Sedangkan untuk variable Perceived Benefit nilai paling kecil adalah 0,833 pada indicator Ben4 dan yang paling besar adalah 0,961 untuk Ben2. Adapun variable Keputusan Memilih, untuk nilai loading paling kecil adalah 0,949 untuk indicator Kep1 dan yang paling besar adalah 0,985 untuk indicator Kep3. . Dilihat dari keseuruhan indicator yang diteliti nilai paling kecil adalah sebesar 0,602 untuk indikator Dem3 (demografi) sedangkan nilai paling besar adalah 0,985 untuk indikator Kep3 (keputusan memilih). Artinya indikator yang dipergunakan dalam penelitian ini adalah valid atau telah memenuhi convergent validity.

Indikator reflektif juga perlu diuji discriminant validity dengan cross loading, output dari Cross Loadings ini menghendaki bahwa nilai korelasi dari setiap indikator dengan variabel latennya, harus lebih besar, bila dibandingkan dengan korelasi antara indicator, sebagai berikut:

\section{RESULT FOR CROSS LOADING}

\begin{tabular}{|r|r|r|r|r|}
\hline & Brand Image & Demografi & Keputusan & Perceived Benefit \\
\hline Ben1 & 0,854 & 0,541 & 0,786 & $\mathbf{0 , 9 1 9}$ \\
\hline Ben2 & 0,878 & 0,551 & 0,854 & $\mathbf{0 , 9 6 1}$ \\
\hline Ben3 & 0,830 & 0,525 & 0,832 & $\mathbf{0 , 9 1 1}$ \\
\hline Ben4 & 0,717 & 0,408 & 0,738 & $\mathbf{0 , 8 3 3}$ \\
\hline Brim1 & $\mathbf{0 , 6 6 0}$ & 0,643 & 0,510 & 0,458 \\
\hline Brim2 & $\mathbf{0 , 7 9 1}$ & 0,547 & 0,686 & 0,642 \\
\hline Brim3 & $\mathbf{0 , 7 2 8}$ & 0,521 & 0,634 & 0,590 \\
\hline Brim4 & $\mathbf{0 , 8 1 0}$ & 0,635 & 0,641 & 0,714 \\
\hline Brim5 & $\mathbf{0 , 8 3 1}$ & 0,596 & 0,660 & 0,715 \\
\hline Brim6 & $\mathbf{0 , 9 0 4}$ & 0,573 & 0,840 & 0,878 \\
\hline Brim7 & $\mathbf{0 , 8 7 0}$ & 0,478 & 0,804 & 0,845 \\
\hline Brim8 & $\mathbf{0 , 9 1 2}$ & 0,548 & 0,813 & 0,892 \\
\hline Brim9 & $\mathbf{0 , 9 0 4}$ & 0,560 & 0,801 & 0,889 \\
\hline Dem1 & 0,565 & $\mathbf{0 , 8 1 5}$ & 0,455 & 0,495 \\
\hline Dem2 & 0,550 & $\mathbf{0 , 7 6 0}$ & 0,454 & 0,449 \\
\hline Dem3 & 0,342 & $\mathbf{0 , 6 0 2}$ & 0,253 & 0,255 \\
\hline Dem4 & 0,519 & $\mathbf{0 , 8 2 7}$ & 0,462 & 0,427 \\
\hline \hline & & & & \\
\hline \hline
\end{tabular}




\begin{tabular}{|r|r|r|r|r|}
\hline Dem5 & 0,603 & $\mathbf{0 , 8 6 8}$ & 0,521 & 0,505 \\
\hline Kep1 & 0,841 & 0,536 & $\mathbf{0 , 9 4 9}$ & 0,861 \\
\hline Kep2 & 0,871 & 0,552 & $\mathbf{0 , 9 7 4}$ & 0,878 \\
\hline Kep3 & 0,852 & 0,561 & $\mathbf{0 , 9 8 5}$ & 0,867 \\
\hline Kep4 & 0,793 & 0,536 & $\mathbf{0 , 9 6 0}$ & 0,818 \\
\hline
\end{tabular}

Suatu indikator dinyatakan valid jika mempunyai loading factor tertinggi kepada konstruk yang dituju dibandingkan loading factor kepada konstruk lain. Tabel di atas menunjukkan bahwa loading factor untuk indikator Perceived Benefit (Ben1-Ben4) mempunyai loading factor kepada konstruk Perceived Benefit lebih tinggi dari pada dengan konstruk yang lain. Sebagai ilustrasi loading factor paling kecil pada variable Perceived Benefit yaitu Ben4 kepada Perceived Benefit adalah sebesar 0,833 lebih tinggi dari pada loading factor kepada Brand Image $(0,717)$, Demografi $(0,408)$ dan Keputusan $(0,738)$. Sedangkan paling besar adalah Ben2 yaitu 0,961 lebih tinggi dari pada loading factor kepada Brand Image $(0,878)$, Demografi $(0,551)$ dan Keputusan $(0,854)$.

Hal serupa juga tampak pada variable Brand Image indicator dengan loading factor paling kecil diantara indicator pada variable brand image adalah Ben1 yaitu 0,660 lebih tinggi dari pada loading faktor kepada demografi $(0,643)$, keputusan $(0,510)$ dan kepada perceived benefit $(0,458)$ sedangkan loading factor paling besar adalah Brim8 0,912 lebih tinggi dari pada loading factor kepada demografi $(0,548)$, keputusan $(0,813)$ dan kepada perceived benefit $(0,892)$.

Pada variable Demografi indicator dengan loading factor paling kecil diantara indicator pada variable demografi adalah Dem3 yaitu 0,602 lebih tinggi dari pada loading faktor kepada brand image $(0,342)$, keputusan $(0,253)$ dan kepada perceived benefit $(0,505)$ sedangkan loading factor paling besar adalah Dem5 0,868 lebih tinggi dari pada loading factor kepada brand image $(0,603)$, keputusan $(0,521)$ dan kepada perceived benefit $(0,505)$.

Pada variable Keputusan indicator dengan loading factor paling kecil diantara indicator pada variable keputusan adalah Kep1 yaitu 0,949 lebih tinggi dari pada loading faktor kepada brand image $(0,841)$, demografi $(0,536)$ dan kepada perceived benefit $(0,861)$ sedangkan loading factor paling besar adalah Kep3 yaitu 0,985 lebih tinggi dari pada loading factor kepada brand image $(0,852)$, demografi $(0,561)$ dan kepada perceived benefit $(0,867)$.

Dari keseluruhan indicator yang memiliki loading factor paling tinggi adalah Kep3 yaitu 0,985 lebih tinggi daripada loading factor kepada brand image $(0,852)$, demografi $(0,561)$ dan kepada perceived 
benefit $(0,867)$ sedangkan paling kecil adalah Dem3 yaitu 0,602 lebih tinggi dari pada loading faktor kepada brand image $(0,342)$, keputusan $(0,253)$ dan perceived benefit $(0,505)$. Dengan demikian, konstruk laten memprediksi indikator pada blok mereka lebih baik dibandingkan dengan indikator di blok yang lain.

Metode lain untuk melihat discriminant validity adalah dengan melihat nilai square root of average variance extracted (AVE). Nilai yang disarankan adalah di atas 0,5 . Berikut adalah nilai AVE dalam penelitian ini:

AVERAGE VARIANCE EXTRACTED (AVE)
\begin{tabular}{|l|l|}
\hline & Average variance extracted \\
\hline Brand Image & 0,685 \\
\hline Demografi & 0,608 \\
\hline Keputusan Memilih & 0,935 \\
\hline Perceived Benefit & 0,823 \\
\hline
\end{tabular}

Tabel di atas memberikan nilai AVE di atas 0,5 untuk semua konstruk yang terdapat pada model penelitian. Nilai terendah AVE adalah sebesar 0,608 pada konstruk Demografi. Dan nilai tertinggi AVE adalah sebesar 0,935 pada konstruk Keputusan Memilih. Berikutnya untuk konstruk Brand Image nilai AVE adalah sebesar 0,685 dan untuk variable Perceived Benefit nilai AVE adalah 0,823. Sehingga variablevariabel tersebut sudah memenuhi discrimant validity yang artinya valid.

\section{b. Uji Reliabilitas}

Uji keandalan data dilakukan dengan composite reliability. Chin $\mathrm{W}^{19}$ (1998) mengatakan bahwa "The unidimensionality of the block of variables may be assessed by using composite reliability (should be $>0.7$ )". Uji reliabilitas dilakukan dengan melihat nilai composite reliability dari blok indikator yang mengukur konstruk. Hasil composite reliability akan menunjukkan nilai yang memuaskan jika di atas 0,7. Berikut adalah nilai composite reliability pada output:

\section{COMPOSITE RELIABILITY}

\begin{tabular}{|l|l|}
\hline & Composite Reliability \\
\hline Brand Image & 0,951 \\
\hline Demografi & 0,884 \\
\hline
\end{tabular}

\footnotetext{
${ }^{19}$ Chin, W. W. The partial least squares approach for structural equation modeling. 295-
} 336 


\begin{tabular}{|l|l|}
\hline Keputusan Memilih & 0,983 \\
\hline Perceived Benefit & 0,949 \\
\hline
\end{tabular}

Tabel di atas menunjukkan bahwa nilai composite reliability untuk semua konstruk adalah di atas 0,7 yang menunjukkan bahwa semua konstruk pada model yang diestimasi memenuhi kriteria discriminant validity. Nilai composite reliability yang terendah adalah sebesar 0,884 pada konstruk Demografi. Nilai composite reliability yang paling besar adalah Keputusan Memilih sebesar 0,983. Kemudian nilai Brand Image adalah 0,951 dan nilai Perceived Benefit adalah 0,949. Memperhatikan hasil Composite Reliability diatas, keseluruhan hasil uji berada diatas 0,70. Maka dengan demikian dapat disimpulkan bahwa variabel demografi, brand image, perceived benefit dan keputusan memilih adalah reliabel dan terandalkan dan dapat dipergunakan untuk uji hipotesis.

Uji reliabilitas juga bisa diperkuat dengan Cronbach's Alpha. Cronbach alpha adalah tingkat konsistensi jawaban responden dalam satu variabel laten. Umumnya untuk riset pada tingkat skripsi adalah $>0,60$ dan untuk riset untuk tesis dan disertasi adalah $>0,70$. Pada penelitian ini output SmartPLS Versi 3 memberikan hasil sebagai berikut:

CRONBACH'S ALPHA

\begin{tabular}{|l|l|}
\hline & Cronbachs Alpha \\
\hline Brand Image & 0,941 \\
\hline Demografi & 0,837 \\
\hline Keputusan Memilih & 0,977 \\
\hline Perceived Benefit & 0,927 \\
\hline \hline
\end{tabular}

Nilai yang disarankan adalah di atas 0,7 dan pada tabel di atas menunjukkan bahwa nilai Cronbach's Alpha untuk semua konstruk berada di atas 0,7. Nilai terendah adalah sebesar 0,837 untuk konstruk Demografi. Dan Keputusan Memilih memiliki nilai cronbach's alpha paling tinggi yaitu 0,977. Sedangkan Brand Image memiliki nilai 0,941 dan Perceived Benefit bernilai 0,927. Hal ini setiap konstruk yang telah diteliti telah memenuhi syarat reliable.

\section{Pengujian Model Struktural}

Uji pada model struktural dilakukan untuk menguji hubungan antara konstruk laten. Ada beberapa uji untuk model struktural yaitu :

\section{a. $\mathbf{R}$ Square}


Nilai $\mathrm{R}^{2}$ adalah koefisien determinasi pada konstruk endogen. Nilai ${ }^{20} \mathrm{R}^{2}$ sebesar 0,67 dikategorikan substansial, 0,33 dikategorikan sebagai moderat, 0,19 dikategorikan sebagai lemah. Sedangkan >0,7 dikategorikan sebagai kuat.

Setelah model yang diestimasi memenuhi kriteria Outer Model, berikutnya dilakukan pengujian model structural (Inner model). Berikut adalah nilai R-Square pada konstruk:

\begin{tabular}{|l|l|}
\hline \multicolumn{1}{c|}{ R-SQUARE } \\
\begin{tabular}{|l|l|}
\hline \multicolumn{1}{c|}{ R-square } \\
\hline Keputusan Memilih & 0,810 \\
\hline Demografi & \\
\hline Brand Image & \\
\hline Perceived Benefit & \\
\hline
\end{tabular}
\end{tabular}

Tabel di atas memberikan nilai 0,810 untuk konstruk Keputusan Memilih yang berarti kemampuan variable demografi, brand image dan perceived benefit dalam menjelaskan keputusan memilih adalah $81 \%$. Dari tabel di atas diperoleh nilai $\mathrm{R}^{2}$ square dengan kategori kuat. Kesimpulannya model yang menghubungkan antar variable laten kuat, dengan di dapat nilai $\mathrm{R}^{2}>0,7$

\section{b. Estimate for Path Coefficients}

Merupakan nilai koefisen jalur atau besarnya hubungan/pengaruh konstruk laten. Dilakukan dengan prosedur Bootrapping.

\section{PATH COEFFICIENTS}

\begin{tabular}{|l|l|l|l|l|l|}
\hline & $\begin{array}{c}\text { Original } \\
\text { Sample }\end{array}$ & $\begin{array}{c}\text { Sample Mean } \\
(\mathrm{M})\end{array}$ & $\begin{array}{c}\text { Standard } \\
\text { Error }\end{array}$ & $\begin{array}{c}\text { T } \\
\text { Statistics }\end{array}$ & P Value \\
\hline $\begin{array}{l}\text { Brand Image } \rightarrow \text { Keputusan } \\
\text { Memilih }\end{array}$ & 0,356 & 0,361 & 0,206 & 1,729 & 0,084 \\
\hline $\begin{array}{l}\text { Demografi } \rightarrow \text { Keputusan } \\
\text { Memilih }\end{array}$ & 0,013 & 0,017 & 0,065 & 0,205 & 0,837 \\
\hline $\begin{array}{l}\text { Perceived } \\
\text { Benefit } \rightarrow \text { Keputusan } \\
\text { Memilih }\end{array}$ & 0,556 & 0,548 & 0,194 & 2,860 & 0,004 \\
\hline
\end{tabular}

Path Coefficient menunjukkan bahwa semua pengujian variabel antar variabel adalah signifikan kecuali variabel demografi dengan nilai T_statistik dalam level berapapun tidak memenuhi syarat signifikansi. Dengan demikian dapat disimpulkan bahwa hipotesis 2 dan 3 dapat

${ }^{20}$ Chin, W. W, The partial least squares approach, 295-336. 
diterima. Sedangkan hipotesisi 1 ditolak atau tidak berpengaruh secara signifikan.

\section{Pengujian Inner Model}

Outer Weight memperlihatkan bahwa tiap indikator signfikan terhadap variabel latennya, karena t statistiknya $>1,96$ (pada tingkat signifikansi 0,1).

OUTER WEIGHTS

\begin{tabular}{|c|c|c|c|c|}
\hline & $\begin{array}{c}\text { Original } \\
\text { Sample }(\mathrm{O})\end{array}$ & $\begin{array}{c}\text { Sample } \\
\text { Mean (M) }\end{array}$ & $\begin{array}{l}\text { Standard } \\
\text { Error }\end{array}$ & $\begin{array}{c}\text { T Statistics } \\
(|\mathrm{O} / \mathrm{STERR}|)\end{array}$ \\
\hline Ben1 $\leftarrow$ Perceived Benefit & 0,270 & 0,270 & 0,019 & 13,956 \\
\hline Ben $2 \leftarrow$ Perceived Benefit & 0,293 & 0,292 & 0,017 & 17,477 \\
\hline Ben $3 \leftarrow$ Perceived Benefit & 0,285 & 0,285 & 0,022 & 13,257 \\
\hline Ben $4 \leftarrow$ Perceived Benefit & 0,253 & 0,253 & 0,026 & 9,763 \\
\hline Brim $1 \leftarrow$ Brand Image & 0,096 & 0,096 & 0,014 & 6,742 \\
\hline Brim $2 \leftarrow$ Brand Image & 0,129 & 0,129 & 0,011 & 11,250 \\
\hline Brim $3 \leftarrow$ Brand Image & 0,119 & 0,119 & 0,011 & 11,120 \\
\hline Brim $4 \leftarrow$ Brand Image & 0,120 & 0,120 & 0,008 & 14,217 \\
\hline Brim $5 \leftarrow$ Brand Image & 0,124 & 0,124 & 0,010 & 12,771 \\
\hline Brim $6 \leftarrow$ Brand Image & 0,158 & 0,157 & 0,009 & 18,431 \\
\hline Brim $7 \leftarrow$ Brand Image & 0,151 & 0,150 & 0,010 & 14,734 \\
\hline Brim $8 \leftarrow$ Brand Image & 0,152 & 0,153 & 0,011 & 14,310 \\
\hline Brim $9 \leftarrow$ Brand Image & 0,150 & 0,150 & 0,09 & 16,417 \\
\hline Dem1 $\leftarrow$ Demografi & 0,267 & 0,267 & 0,043 & 6,210 \\
\hline Dem $2 \leftarrow$ Demografi & 0,267 & 0,263 & 0,045 & 5,894 \\
\hline Dem $3 \leftarrow$ Demografi & 0,149 & 0,149 & 0,064 & 2,341 \\
\hline Dem $4 \leftarrow$ Demografi & 0,271 & 0,269 & 0,034 & 8,089 \\
\hline Dem5 $\leftarrow$ Demografi & 0,306 & 0,305 & 0,034 & 9,080 \\
\hline Kep1 $\leftarrow$ Keputusan Memilih & 0,260 & 0,259 & 0,008 & 31,800 \\
\hline Kep $2 \leftarrow$ Keputusan Memilih & 0,266 & 0,266 & 0,006 & 47,192 \\
\hline Kep $3 \leftarrow$ Keputusan Memilih & 0,262 & 0,263 & 0,005 & 49,056 \\
\hline Kep4 $\leftarrow$ Keputusan Memilih & 0,246 & 0,246 & 0,006 & 40,631 \\
\hline
\end{tabular}

Pada table 4.28 diatas dapat dilihat nahwa seluruh indicator yang telah diteliti adalah signifikan, hal ini karena nilai T-Statistik yang dihasilkan telah memenuhi syarat yang disarankan yaitu $>1,96$. 
Variabel Perceived Benefit untuk T-Statistik paling tinggi indikator Ben2 dengan nilai 17,477 sedangkan paling kecil adalah Ben4 dengan nilai 9,763. Variabel Brand Image nilai T-Statistik paling tinggi adalah 18,431 yaitu indicator Brim6 sedangkan paling kecil adalah Brim1 dengan nilai 6,743. Variabel Demografi memiliki nilai T-Statistik 9,080 pada infikator Dem5 sedangkan paling rendah adalah 2,341 pada Dem 3. Variabel Keputusan Memilih memiliki nilai T-Statistik paling tinggi 49,056 pada Kep 3 dan paling rendah adalah 31,800 pada Kep1. Dari seluruh indicator yang diteliti Kep3 dengan nilai T-Statistik 49,056 merupakan nilai paling tinggi diantara semua indicator. Sedangkan Dem3 dengan nilai 2,913 merupakan nilai paling kecil diantara semua indicator yang diteliti namun masih lebih besar daripada nilai T-Statistik yang disarankan.

\section{Uji Hipotesis}

Untuk uji hipotesis dilihat dari nilai Total Effects yang telah dihasilkan pada saat olah data. Berikut adalah nilai yang telah dihasilkan

\section{TOTAL EFFECTS}

\begin{tabular}{|l||r|r|r|r|}
\hline & $\begin{array}{c}\text { Original } \\
\text { Sample }(\mathrm{O})\end{array}$ & $\begin{array}{c}\text { Sample } \\
\text { Mean }(\mathrm{M})\end{array}$ & $\begin{array}{c}\text { Standard } \\
\text { Error }\end{array}$ & $\begin{array}{c}\text { T Statistics } \\
(\mid \mathrm{O} / \text { STERR } \mid)\end{array}$ \\
\hline Brand Image $\rightarrow$ Keputusan Memilih & 0,356 & 0,361 & 0,206 & 1,729 \\
\hline Demografi $\rightarrow$ Keputusan Memilih & 0,013 & 0,017 & 0,065 & 0,205 \\
\hline $\begin{array}{l}\text { Perceived Benefit } \rightarrow \text { Keptusan } \\
\text { Memilih }\end{array}$ & 0,556 & 0,548 & 0,194 & 2,860 \\
\hline
\end{tabular}

Tabel di atas menunjukkan bahwa hubungan antara Demografi dengan Keputusan Memilih adalah tidak signifikan dengan T-statistik sebesar 0,205 (< 1,96). Nilai original sample estimate adalah positif yaitu sebesar 0,013 yang menunjukkan bahwa arah hubungan antara Demografi dengan Keputusan Memilih adalah positif. Dengan demikian hipotesis H1 dalam penelitian ini yang menyatakan bahwa Demografi berpengaruh terhadap Keputusan Memilih ditolak.

Hubungan antara Brand Image dengan Keputusan Memilih adalah signifikan dengan T-statistik sebesar 1,729 pada level $10 \%(>1,654)$ sedangkan pada level 5\% tidak terpengaruh. Nilai original sample estimate adalah positif yaitu sebesar 0,356 atau 35,6\% yang menunjukkan bahwa arah hubungan antara Brand Image dengan Keputusan Memilih adalah positif. Dengan demikian hipotesis $\mathrm{H} 2$ dalam penelitian ini yang menyatakan bahwa Brand Image berpengaruh terhadap Keputusan Memilih (bias) diterima.

Hubungan antara Perceived Benefit dengan Keputusan Memilih adalah signifikan dengan T-statistik sebesar 2,860 (> 1,96). Nilai original 
sample estimate adalah positif yaitu sebesar 0,556 yang menunjukkan bahwa arah hubungan antara Perceived Benefit dengan Keputusan Memilih adalah positif. Dengan demikian hipotesis H3 dalam penelitian ini yang menyatakan bahwa Perceived Benefit berpengaruh terhadap Keputusan Memilih diterima.

Berdasarkan nilai original sample estimate maka diperoleh bahwa nilai tertinggi yang mempengaruhi Keputusan Memilih adalah pada Perceived Benefit yaitu sebesar 0,556 atau 55,6\%. Hal tersebut menunjukkan bahwa Perceived Benefit mempunyai pengaruh terhadap Keputusan Memilih lebih tinggi dari pada pengaruh antara Brand Image terhadap Keputusan Memilih (0,356). Lebih lanjut, dari tiga variabel yang mempengaruhi Keputusan Memilih secara langsung, yaitu demografi, brand image dan perceived benefit, yang paling besar pengaruhnya adalah perceived benefit karena mempunyai nilai original sample estimate tertinggi. Dengan demikian perceived benefit merupakan variabel yang paling dominan dalam mempengaruhikeputusan memilih. Sedangkan variabel yang paling tidak dominan adalah demografi.

Dari hasil analisis yang terlihat pada Loading Factor untuk indikator dapat disimpulkan bahwa pada variable Demografi indikator Dem5 yang paling berpengaruh terhadap keputusan memilih dengan nilai 0,868 atau $86,8 \%$ sedangkan yang paling kecil adalah Dem3 yaitu 0,602 atau berpengaruh terhadap keputusan memilih sebesar $60,2 \%$ saja. Sedangkan pada variable Brand Image dapat dilihat indicator Brim8 memiliki pengaruh paling tinggi terhadap Keputusan Memilih yaitu sebesar 0,912 atau $91,2 \%$ dan yang nilai pengaruhnya paling kecil adalah Brim1 yaitu 0,660 atau sebesar 66\%. Dan pada variable Perceived Benefit dapat dilihat indicator Ben4 memiliki pengaruh paling tinggi terhadap Keputusan Memilih yaitu sebesar 0,833 atau 83,3\% dan yang nilai pengaruhnya paling kecil adalah Ben2 yaitu 0,961 atau sebesar 96,1\%. Dapat disimpulkan bahwa variable yang paling berpengaruh terhadap Keputusan Memilih adalah variable Perceived Benefit dan variable yang paling tidak berpengaruh adalah Demografi. Sedangkan indicator yang paling berpengaruh terhadap Keputusan Memilih adalah Ben2 dan yang memiliki pengaruh kecil terhadap loyalitas pada penelitian ini adalah Dem3.

\section{HASIL ANALISA}

Dari hasil analisis statistic dengan menggunakan uji model, diketahui bahwa variabel X1 tidak berpengaruh signifikan terhadap Y (Keputusan Memilih), sedangkan 2 (dua) variabel lainnya yaitu X2 (Brand Image) dan X3 (Perceived Benefit) berpengaruh signifikan 
terhadap variabel Y (Keputusan Memilih). Pengaruh-pengaruh dan hipotesis yang ada akan diuraikan pada penjelasan dibawah ini.

\section{Hipotesis 1}

\section{Demografi berpengaruh terhadap Keputusan Nasabah}

Hipotesis 1 adalah demografi berpengaruh terhadap keputusan memilih menjadi mitra nasabah di PT. BPRS Lantabur Tebuireng Cab. Mojokerto. Nilai dari total effect hubungan antara demografi terhadap keputusan memilih adalah tidak signifikan dengan T-statistik sebesar $0,205(<1,96)$ dilihat dari level tingkat signifikansi $1 \%, 5 \%$, atau $10 \%$ nilai $\mathrm{T}$ statistic yang dihasilkan hipotesis ini terlalu kecil sehingga disimpulkan bahwa hipotesis 1 tidak terbukti pada PT. BPRS Lantabur Tebuireng Cab. Mojokerto. Nilai original sample estimate yaitu sebesar 0,013 atau $13 \%$ yang menunjukkan bahwa pengaruh hubungan antara demografi gterhadap keputusan memilih sangat terlalu kecil. Sehingga dapat simpulkan bahwa dalam populasi dan sampel di PT. BPRS Lantabur Tebuireng Cab. Mojokerto, variable demografi tidak berpengaruh terhadap keputusan memilih.

Adapun terkait hasil penelitian yang penulis lakukan tidak ada pengaruh signifikan antara variable demografi dengan keputusan memilih pada hasil penelitian di PT. BPRS Lantabur Tebuireng Cab. Mojokerto, secara logis dibuktikan dengan hasil wawancara dengan responden mereka mengatakan keputusan untuk memilih bergabung bukan karena jenis kelamin, usia, tingkat pendidikan, pekerjaan atau pendapatan tapi karena manfaat yang diberikan PT. BPRS Lantabur Tebuireng Cab. Mojokerto. Bagi mereka yang menabung memilih bank tersebut karena letaknya strategis dekat dengan fasilitas publik, kelebihan nya lagi adalah karyawan mau untuk menjemput bola artinya transaksi bisa diambil oleh karyawan sehingga nasabah tidak perlu bersusah payah untuk datang ke tempat, niat mereka memang ingin bergabung dikarenakan bank memberi jaminan kehalalan produk serta jasa, produk-produk yang dimiliki sesuai dan dapat dijangkau oleh setiap kalangan seperti tabungan haji yang lebih murah dan banyak memberikan keringan.

\section{Hipotesis 2}

\section{Brand Image berpengaruh Keputusan Memilih nasabah.}

Hipotesis ini bertujuan untuk menguji apakah Brand Image berpengaruh signifikan terhadap Keputusan Memilih nasabah di PT. BPRS Lantabur Tebuireng Cab. Mojokerto. Berdasarkan nilai dari total effect hubungan antara Brand Image terhadap Keputusan Memilih adalah signifikan dengan T-statistik sebesar 1,729) (> 1,645 nilai t table 
pada taraf $10 \%)^{21}$. Nilai original sample estimate adalah positif yaitu sebesar 0,356 atau 35,6\% yang menunjukkan bahwa arah hubungan antara Brand Image terhadap Keputusan Memilih adalah positif. Artinya variable Keputusan Memilih dipengaruhi oleh variable Brand Image sebesar 35,6\%. Sehingga dapat disimpulkan bahwa Brand Image memiliki pengaruh terhadap Keputusan Memilih nasabah menjadi mitra PT. BPRS Lantabur Tebuireng Cab. Mojokerto.

Hasil penelitian ini menunjukan bahwa Citra perusahaan memiliki peran yang besar dalam mempengaruhi keputusan pembelian konsumen. Popularitas perusahaan serta kemampuan perusahaan dalam melayani dan memenuhi kebutuhan konsumen sangat menentukan bagaimana kesan masyarakat terhadap citra perusahaan tersebut. Perusahaan yang memiliki citra baik produk-produknya cenderung lebih disukai dan mudah diterima dari pada perusahaan yang memiliki citra kurang baik atau citra yang netral. Citra perusahaan seringkali dijadikan acuan oleh konsumen untuk memutuskan keputusan pembelian ketika konsumen tersebut tidak memiliki pengalaman atau pengetahuan akan suatu produk. Citra pemakai sangat erat hubungannya dengan kepribadian konsumen. Dalam banyak peristiwa, sering kita temukan ketika seorang konsumen memilih suatu produk atau merek berdasarkan tipe atau kepribadian mereka. Konsumen yang memiliki kepribadian dan gaya hidup yang modern cenderung lebih menyukai produk-produk yang bergaya modern dari pada produk-produk yang bergaya tradisional atau kuno, begitu pula sebaliknya. Citra produk adalah kesan yang diterima oleh masyarakat terhadap suatu produk. Citra produk yang dirasa menyenangkan mempunyai peluang yang jauh lebih baik untuk dibeli dari pada produk yang mempunyai citra tidak menyenangkan atau netral.

\section{Hipotesis 3}

\section{Perceived Benefit berpengaruh terhadap Keputusan Nasabah}

Dari hasil analisis yang terlihat pada nilai table path coefficient, pengaruh variable Perceived Benefit terhadap Keputusan Memilih dengan nilai original sample 0,556 dan T Statistik 2,860 dapat disimpulkan bahwa variable Perceived Benefit memiliki pengaruh 0,556 atau 55,6\% terhadap Keputusan Memilih dengan T statistik pada 2,860 (> 1,96) yang artinya signifikan pada taraf $5 \%$.

\section{KESIMPULAN}

21 Menurut Ghazali, tidak ada ukuran yang pasti mengenai seberapa besar level signifikansi, tetapi pada umumnya level signifikansi adalah 1\%, 5\% dan 10\%. Dan T statistic dalam hipotesisi 2 masih berada dalam tingkat level yang disarankan sehingga hipotesisi diterima.( Ghazali, Structural Equation Modelling: Lisrel). 84 
Kesimpulan dari penelitian ini adalah variabel demografi tidak berpengaruh signifikan terhadap variabel keputusan memilih nasabah, sedangkan kedua variabel yaitu brand image dan perceived benefit berpengaruh signifikan terhadap keputusan memilih nasabah di PT. BPRS Lantabur Tebuireng Cab. Mojokerto. Untuk lebih jelasnya, kesimpulan penelitian dapat dilihat dalam paparan berikut

1. Hipotesis 1 adalah Demografi tidak berpengaruh signifikan terhadap keputusan memilih menjadi mitra nasabah di PT. BPRS Lantabur Tebuireng Cab. Mojokerto. Nilai dari total effect hubungan antara demografi terhadap keputusan memilih adalah tidak signifikan dengan T-statistik sebesar 0,205 $(<1,96)$ dilihat dari level tingkat signifikansi $1 \%, 5 \%$, atau $10 \%$ nilai $\mathrm{T}$ statistic yang dihasilkan hipotesis ini terlalu kecil sehingga disimpulkan bahwa hipotesis 1 tidak terbukti pada PT. BPRS Lantabur Tebuireng Cab. Mojokerto. Nilai original sample estimate yaitu sebesar 0,013 atau 13\% yang menunjukkan bahwa pengaruh hubungan antara demografi gterhadap keputusan memilih sangat terlalu kecil. Sehingga dapat simpulkan bahwa dalam populasi dan sampel di PT. BPRS Lantabur Tebuireng Cab. Mojokerto, variable demografi tidak berpengaruh terhadap keputusan memilih.

2. Hipotesis 2 adalah Brand Image berpengaruh signifikan terhadap Keputusan Memilih nasabah di PT. BPRS Lantabur Tebuireng Cab. Mojokerto. Berdasarkan nilai dari total effect hubungan antara Brand Image terhadap Keputusan Memilih adalah signifikan dengan T-statistik sebesar 1,729 (>1,645 nilai t table pada taraf $10 \%)^{22}$. Nilai original sample estimate adalah positif yaitu sebesar 0,356 atau $35,6 \%$ yang menunjukkan bahwa arah hubungan antara Brand Image terhadap Keputusan Memilih adalah positif. Artinya variable Keputusan Memilih dipengaruhi oleh variable Brand Image sebesar 35,6\%. Sehingga dapat disimpulkan bahwa Brand Image memiliki pengaruh terhadap Keputusan Memilih nasabah menjadi mitra PT. BPRS Lantabur Tebuireng Cab. Mojokerto.

3. Hipotesis 3 adalah Perceived Benefit berpengaruh signifikan terhadap Keputusan Memilih nasabah di PT. BPRS Lantabur Tebuireng Cab. Mojokerto. Dari hasil analisis yang terlihat pada nilai table path coefficient, pengaruh variable Perceived Benefit terhadap Keputusan Memilih dengan nilai original sample 0,556 dan $\mathrm{T}$

\footnotetext{
${ }^{22}$ Menurut Ghazali, tidak ada ukuran yang pasti mengenai seberapa besar level signifikansi, tetapi pada umumnya level signifikansi adalah 1\%, 5\% dan 10\%. Dan T statistic dalam hipotesisi 2 masih berada dalam tingkat level yang disarankan sehingga hipotesisi diterima.( Ghazali, Structural Equation Modelling: Lisrel). 84
} 
Statistik 2,860 dapat disimpulkan bahwa variable Perceived Benefit memiliki pengaruh 0,556 atau 55,6\% terhadap Keputusan Memilih dengan T statistik pada 2,860 (>1,96) yang artinya signifikan pada taraf $5 \%$.

4. Variabel Perceived Benefit berpengaruh paling signifikan dibanding variabel Demografi dan Brand Image. Hasil pengujian membuktikan bahwa persepsi manfaat mempunyai pengaruh secara signifikan terhadap Keputusan Memilih. Perceived benefit (persepsi manfaat) merupakan keyakinan konsumen tentang sejauh mana ia akan menjadi lebih baik. Secara keseluruhan konsumen yang belum pernah menggunakan produk dan jasa PT. BPRS Lantabur Tebuireng Cab. Mojokerto memiliki persepsi yang tinggi mengenai manfaat yang didapat jika menggunakan. Hasil penelitian tersebut menunjukkan bahwa manfaat yang dirasakan berpengaruh positif terhadap niat menggunakan jasa PT. BPR Syari'ah Lantabur Tebuireng Cab. Mojokerto.

\section{Daftar pustaka}

Muhammad, Manajemen Bank Syariah Edisi Revisi Ke-2 (Yogyakarta: UPP STIM YKPN, 2011).

Aan Zainul Anwar dan M. Yunies Edward, "Analisis Shari'ah Compliance Pembiayaan Murabahah Pada Gabungan Koperasi BMT Mitra Se-Kabupaten Jepara", The $3^{\text {rd }}$ University Research Colloquium, 2407-9189 ( Pebruari, 2016).

Budisantoso, Totok dan Nuritom, Bank dan Lembaga Kenangan Lainnya, ( Jakarta: Salemba Empat, 2014).

Kotler, Philip dan Kevin Lane Keller, Manajemen Pemasaran, Edisi ke 12, terj., Benjamin Molan, (Jakarta: PT. Indeks, 2008).

Peter, J. Paul dan Jerry C. Olson, Consumer Behavior. Perilaku konsumen dan Strategi Pemasaran. Jilid 2. Edisi 4. terj., Damos Sihombing, (Jakarta: Erlangga, 2000).

Schiffman, Leon dan Leslie L. Kanuk, Perilaku Konsumen. Edisi Ketujuh, terj., Zoelkifli Kasip (Jakarta: Indeks, 2008).

Lin, Nan-Hong dan Bih-Syah Lin, "The Effect of Brand Image and Product Knowledge on Purchase Intention Moderated by Price Discount", Journal of International Managements Studies, No. 3 ( Agustus, 2007).

Ferrinadewi, Erna, Merek dan Psikologi Konsumen, Implikasi pada Strategi Pemasaran (Yogyakarta: Graha Ilmu, 2008). 
Xian, Gou Li, dkk. 2011. "Corporate-, Product-, and User-Image Dimensions and Purchase Intentions, The Mediating Role of Cognitive and Affective Attitudes", Journal of Computers, Vol. 6, No. 9 (September, 2011).

Khoirunnisa, Delta, "Consumers Preference Toward Islamic Banking Case Study in Bank Muamalat Indonesia and Bank BNI syari'ah", IQTISAD Journal of Islamic Economic. Vol. 4 , No.2 ( September, 2003).

Ratnawati, Nirdukita, "Analisis Pengaruh Variabel Indikator Makro Ekonomi Terhadap Ekonomi Makro Indonesia Periode 19902003", Media Ekonomi Vol. 10 No. 3 (2004).

Fatmah, 'Pengaruh Persepsi Religiusitas, Kualitas Layanan, dan Inovasi

Produk terhadap Kepercayaan dan Komitmen sertaLoyalitas

Nasabah Bank Umum Syari'ah di Jawa Timur', (Disertasi-UNAIR, Surabaya, 2004).

Xian, Gou Li, dkk. 2011. "Corporate-, Product-, and User-Image Dimensions and Purchase Intentions" Journal of Computers Vol.6 No. 9 (2011), 1876.

Hengky Latan dan Imam Ghozali, Partial Least Squares: Konsep, Teknik dan Aplikasi dengan program SmartPLS 2.0 M3 (Semarang: BP UNDIP, 2012).

Chin, W. W. The partial least squares approach for structural equation modeling. 